measured conductance is in proportion to the decreased volume of titrant and is also proportional to the decrease of titrant concentration, the desired value $(n v)$ can be obtained in an electrical signal.

The method was used in the automatic titration of sodium hydroxide with hydrochloric acid.
Reproducibility and accuracy were within the limits of normal titrimetric analysis. Details of the instrumentations and experimental results applied to various types of automatic titrator are presented and possible interferences are also discussed.

(Received Aug. 11, 1964)

\title{
アルカリおよびアルカリ土類金属イオンの 交流ポーラログラフ分析
}

\author{
石橋 信彦，小原 人司，原口 俊秀*
}

\begin{abstract}
交流ポーラログラフ法による数種のアルカリ扔よでアルカリ土類元素の定量を検討した. ヨウ化テト ラエチルアンモニウム (TEA-I) を支持電解質とすると，マグネシウムイオンを除き，リチウム，ナト リウム，カリウム，カルシウム，バリウムの各イオンは定量に適するよい交流波を示す。拈もにナトリ

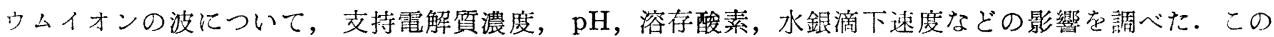
結果にもとづきアルカリ金属打よびバリウムイオンの単独溶液について TEA-I を支持電解質として $10^{-5} \sim 10^{-3} M$ の範囲で直線的な検量線を得た。ナトリウムーカリウム共存系については，テトラフェニ ルホウ素のリチウム塩を用い, カリウムイオンを沈殿分離すれれば， $10^{-4} M$ 程度のナトリウムイオンの定 量が可能で，数倍量共存するカリウムイオンは妨害しない．またカリウムの間接定量も可能である.ア ルカリ土類元素と共存するアルカリ金属イオンも Li-EDTA で前者を陰ぺいて定量できる.
\end{abstract}

\section{1 緒言}

アルカリ金属イオンおよびアルカリ土類金属イオンの ポーラログラフ分析法は，直流法についてはすでに多 数の報告ぶある1) 3). それらによると，これらイオンは $-2.0 \mathrm{~V}$ 付近以上の後放電性のため, 支持電解質として 一般にテトラアルキルアンモニウム塩が用いら机，良好 な波形总得るために有機溶媒あるい法とれと水上の混合 溶媒の利用が推奨されている。李たナトリウムイオンと カリウムイオンが共存する埸合，兩イオンの半波電位は ほとてど等しくその京で活イオンの分析定量が困難

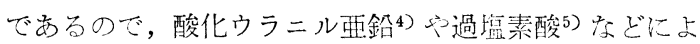
る沈殿分離など検討されている。 そのほか共存系につい ては品川のほとえどすべてのアルカリおよびアルカリ土 類イオンを含む場合の分析的研究2をはじめとしていく つか報告がある・たとえばリチウムおよびカルシウムイ オンの共存はバリウムイオンの波を不明りょうにし2， マグネシウムイオンの共存は他のイオンの定量を著しく 妨害するなどである。

一方, 交流ポーラログラフ法については, Randles

* 九州大学工学部工業分析化学教室 : 福岡市箱崎
ら 6)の電極反応速度の検討のほかは Schwabe らてによ って $10^{-3} \sim 10^{-4} M$ の範围のナトリウムおよびカりウム イオンの分析が報ぜられているだけで, 分析化学的研究 としてはまだ不十分である。そこで，著者らはアルカリ およびアルカリ土類元素の代表として前者についてはり チウム，ナトリウム抢よ゙゙カリウム，後者についてはマ グネシウム，カルシウムさよびバリウムを選び，水溶液 にォけるこれらイオンの交流ポーラログラフ的挙動壳㧍

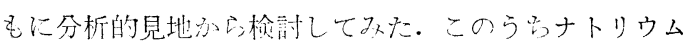
およびカリウムについては Schwabeらより茫干低濃度 宗で調バるとともに，雨イオン其存采の定量も試みた。 またアルカリ土類中のアルカリ金属イオンの分析につい ても簢単に調ベてみた。これらの維果について報告す る.

\section{2 装置および試薬}

\section{$2 \cdot 1$ 装}

装置は柳本交直両用ポーラログラフ PA-102 型を使用 した (重盢交流電圧 : $15 \mathrm{~m} \mathrm{~V}$ ). 電解セルは通常のポーラ ログラフセルを用い，水銀プールを対極とした．水銀滴 下電極の使用条件はこれを検討する場合以外温度 $25^{\circ} \mathrm{C}$ $\pm 0.1^{\circ} \mathrm{C},-1.5 \mathrm{~V}$ （対水銀プール）に扔ける滴下時間 
$4.1 \mathrm{sec}$, 水銀流出速度 $0.5 \mathrm{mg} / \mathrm{sec}$, 窒素通気時間 20 分 である。

\section{$2 \cdot 2$ 試 薬}

使用したアルカリ金属イオン $\left(\mathrm{Li}^{+}, \mathrm{Na}^{+}, \mathrm{K}^{+}\right)$捄よび アルカリ土類金属イオン $\left(\mathrm{Ba}^{2+}, \mathrm{Ca}^{2+}, \mathrm{Mg}^{2+}\right)$ などの標 準溶液はすべて市販の塩化物 (特級試薬) から調製した。

支持電解質のヨウ化テトラエチルアンモニウム(TEA-I) は東京化成製の特級品をそのまま用いた。.アルカリ土類 イオンの陰ぺい剤としての Li-EDTA は水酸化りチウ ム溶液に EDTAの $4 \mathrm{H}$ 形を溶解して調製した。ナトリ ウムイオンとカリウムイオンの分離に用いたリチウムー テトラフェニルホウ素(Li-TPB) はリチウム形のイオン 交換樹脂 Dowex $50 \mathrm{~W}-\mathrm{X} 8(100 \sim 200$ メッシュ) カラ ムを用い，市販の Na-TPB をイオン交換法によりりチ ウム塩に変えた。本法により純粋な Li-TPB が得られ る. この濃度は紫外吸収スペクトルで決定した。水酸化 テトラェチルアンモニウム $(\mathrm{TEA}-\mathrm{OH})$ は水酸化りチウ ムで $\mathrm{OH}$ 形にした陰イオン交換樹脂 (Dowex 1-X 8) カ ラムを用い，とれに TEA-I を通して調製した。

\section{3 実験結果および考察}

\section{$3 \cdot 1$ アルカリおよびアルカリ土類イオンの交流波}

$0.1 M$ TEA-I を支持電解質としたときのリチウム, ナトリウムおよびバリウムイオンの交直両ポーラログラ フを Fig. 1 に示す.これから明らかなように感度およ び分離能とも交流波のほうがはるかに良好である.リチ ウムイオンの波, 特にナトリウムと共存するリチウム波 は他の報告1にもあるように直流法ではほとえど定量不

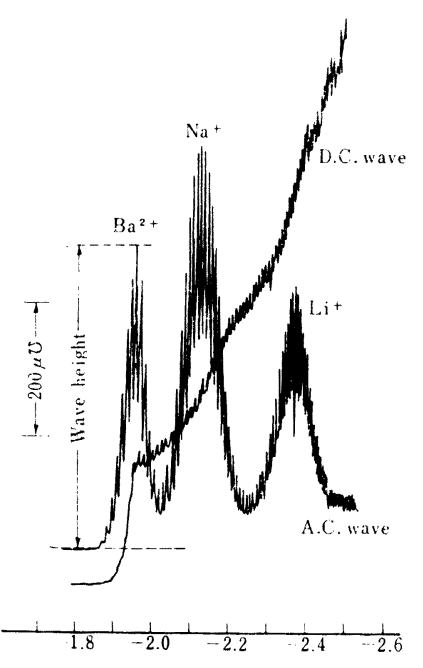

$E, \mathrm{~V} v s . \mathrm{S}$. C. E.

Fig. 1 A. C. and D. C. polarograms of barium, sodium and lithium ions in $0.1 M\left(\mathrm{C}_{2} \mathrm{H}_{5}\right){ }_{4} \mathrm{~N} \cdot \mathrm{I}$ $\mathrm{Li}^{+}, \mathrm{Na}^{+}, \mathrm{Ba}^{2+}: 1 \times 10^{-3} M$
可能であるが, 交流法では明確にあらわれている.カリ ウム波はナトリウムイオンとほとんど同電位にあらわれ る.

カルシウムイオンの直流波は水溶液では極大波を伴い 定量に適しないといわれるが2)，交流法では Fig. 2 に 示すように二つのピークがあらわれる. その一つは頂点 電位が $-2.31 \mathrm{~V}$ (vs. S. C. E.) で, 再現性も十分あり, 定 量に用いうる.これより正の電位にある幅のひろい低い ピークもカルシウムイオン濃度に比例する波高をもって いるが感度の点で劣るので, 本報では前の高いピークに ついてのみ検量線を作成した (3・3). 直流法のカルシウ ム波の半波電位は $\left.-2.2 \mathrm{~V}^{2}\right)$ で一段波である. 交流法で どのような機構で二つの波があらわれるか現在不明であ る.

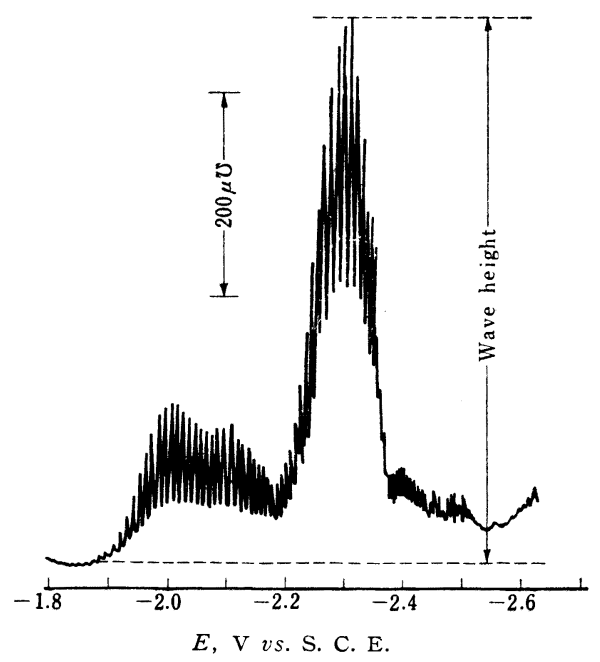

Fig. 2 A. C. polarogram of $1 \times 10^{-3} \mathrm{M} \mathrm{Ca}^{2+}$ in $0.1 M\left(\mathrm{C}_{2} \mathrm{H}_{5}\right)_{4} \mathrm{~N} \cdot \mathrm{I}$

マグネシウムイオンは交流法でも再現性ある波を全く 与えない．また，他のイオンと共存する場合それらイオ ンの定量を著しく阻害することも直流法と同様である.

Table I に二, 三の支持電解質における水銀池対極 に対する頂点電位, Table II に半值幅を示す.

\section{$3 \cdot 2$ 波高に影響を及ぼす諸因子}

次に,アルカリおよびアルカリ土類イオンの交流ポー ラログラフによる定量の基礎的知見をうる目的で支持電 解質濃度, $\mathrm{pH}$, 溶存酸素, 温度および水銀滴下時間示 どの交流波高に及ぼす影響について調べた。これらの諸 因子を検討するために用いた試料は $1 \times 10^{-3} M$ の塩化ナ 
Table I Summit potential, $E_{s}$

\begin{tabular}{lccccc}
\hline \hline $\begin{array}{c}\text { Supporting } \\
\text { electrolyte }\end{array}$ & \multicolumn{5}{c}{$E_{s \dagger}(\mathrm{V})$} \\
\cline { 2 - 6 } & $\mathrm{Na}^{+}$ & $\mathrm{K}^{+}$ & $\mathrm{Li}^{+}$ & $\mathrm{Ba}^{2+}$ & $\mathrm{Ca}^{2+}$ \\
\hline$\left(\mathrm{C}_{2} \mathrm{H}_{5}\right)_{4} \mathrm{~N} \cdot \mathrm{I}$ & -1.81 & -1.84 & -2.05 & -1.65 & -2.01 \\
& $(-2.11)$ & $(-2.14)$ & $(-2.35)$ & $(-1.95)$ & $(-2.31)+\dagger$ \\
$\left(\mathrm{C}_{2} \mathrm{H}_{5}\right)_{4} \mathrm{~N} \cdot \mathrm{OH}$ & -2.00 & -2.03 & -2.26 & -1.82 & -2.30 \\
$\mathrm{LiCl}$ & -2.22 & -2.25 & & -2.07 & \\
\hline
\end{tabular}

$\dagger E_{s}$ (V vs. $\mathrm{Hg}$ pool)

t† Figures in brackets refer to the summit potentials $v s$. S. C. E.

Table II Width of the wave at half height, $\Delta E_{s / 2}$

\begin{tabular}{llllll}
\hline \hline Ion & $\mathrm{Na}^{+}$ & $\mathrm{K}^{+}$ & $\mathrm{Li}^{+}$ & $\mathrm{Ba}^{2+}$ & $\mathrm{Ca}^{2+}$ \\
$\Delta E_{s / 2}(\mathrm{mV})$ & 115 & 112 & 110 & 59 & 111 \\
\hline
\end{tabular}

トリウム溶液で，支持電解質としては TEA-I である.

\section{$\mathbf{3 \cdot 2 \cdot 1}$ 支持電解倎濃度 交流ポーラログラフでは} 直流法よりも高濃度の支持電解質溶液を用いるのが普通 である. そこで電極間距離を $0.5 \mathrm{~cm}$ として支持電解質 濃度と波高の関係について調べた結果を Fig. 3 に示す. これから明らかなように TEA-I を支持電解質とした場 合，濃度約 $0.1 M$ 以上になると波高は一定で定量に影響 しない. 頂点電位は濃度の増加とともに多少変化する。

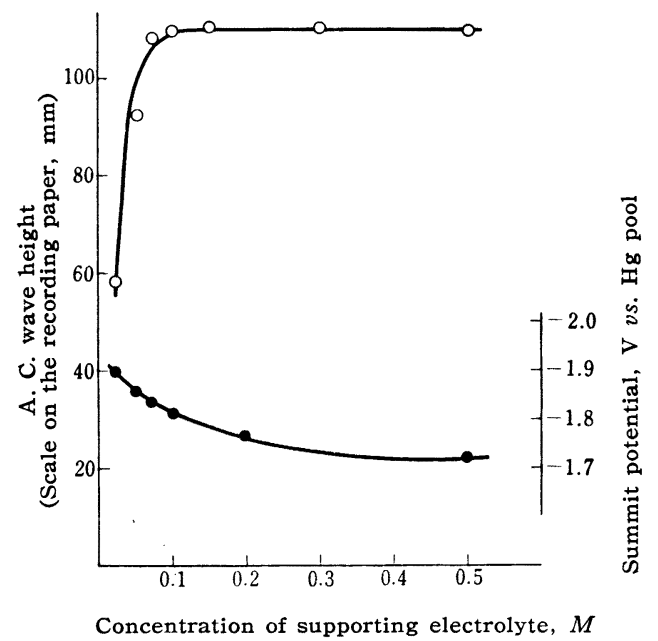

Fig. 3 Effects of the supporting electrolyte concentration on sodium A. C. wave height and summit potential

$\mathrm{NaCl}: 1 \times 10^{-3} M$

Supporting electrolyte : $0.1 M\left(\mathrm{C}_{2} \mathrm{H}_{5}\right)_{4} \mathrm{~N} \cdot \mathrm{I}$

-O- A. C. wave height

- - Summit potential $\mathbf{3 \cdot 2 \cdot 2} \mathbf{p H} \quad \mathrm{pH}$ の調節は酸性側では塩酸で, アル カリ性側は TEA-OH で行なった. $\mathrm{pH} 1$ では交流波 は得られず， $\mathrm{pH} 2$ になると $-1.45 \mathrm{~V}$ (対水銀プール) 付近に頂点電位をもつ交流波が現われるが，これは直流 波と比較して水素波と推測される. pH 3 ではこの水素 波の波高は減少して, 新たに $-1.81 \mathrm{~V}$ にナリウムイ オンによるピークが現われる. 直流ポーラログラフでも 明らかに二段波となる.さらら水素イオン濃度が低下し $\mathrm{pH} 4$ 付近では水素波は消失し，ナトリウムイオンの交 流波のみとなり，その波高は増加する。これにより高い $\mathrm{pH}$ 領域においては pH と波高は Fig. 4 に示すように 一定值をとる.したがって，交流法による定量は $\mathrm{pH} 4$ 以上で行なうほうが望ましい.

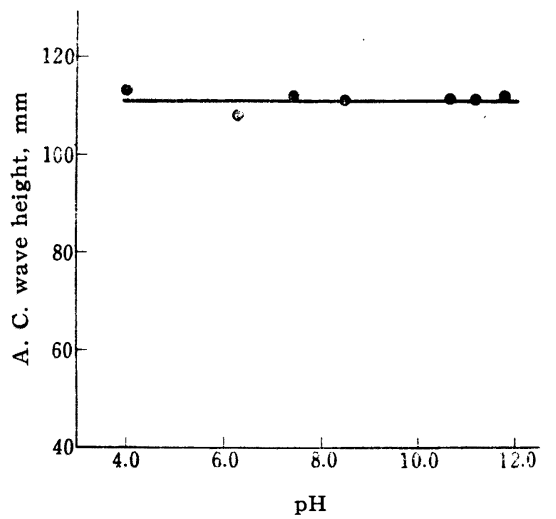

Fig. 4 Effect of $\mathrm{pH}$ on A. C. wave height of sodium

$\mathrm{NaCl}: 1 \times 10^{-3} M$

Supporting electrolyte : $0.1 M\left(\mathrm{C}_{2} \mathrm{H}_{5}\right)_{4} \mathrm{~N} \cdot \mathrm{I}$

$3 \cdot 2 \cdot 3$ 溶存酸素の影響酸素の波は可逆度が低い ので交流ポーラログラフでは溶存酸素を除去しなくても よい場合が多いが，実際に TEA-I を支持電解質として ナトリウム, カリウム, リチウム, バリウムおよびカル シウムイオン溶液について窒素ガスを通じて脱酸素し， 溶存酸素の影響を調べてみた. その結果カリウムイオン の場合は脱酸素しなくても一定の波高が得られたが，そ のほかのイオンでは溶存酸素を除去すると波高は多少増 加する. 特にバリウムイオンの場合著しい. しかし, い ずれの場合も 15 分間程度窒素ガスを通ずれば波高は一 定値に達する.

$3 \cdot 2 \cdot 4$ 電解液温度 温度 $5 \sim 35^{\circ} \mathrm{C}$ の範囲における 温度効果について調べた結果を Fig. 5 に示す.これに よると温度が高くなるほど波高は増加し, 頂点電位は多 
少陰の側に移動し，滴下時間は短くなる．波高に及ぼす 温度勃果 $25^{\circ} \mathrm{C}$ に打ける温度俰数として 約 $+1.5 \%$ で, 直流法における温度係数に近い。

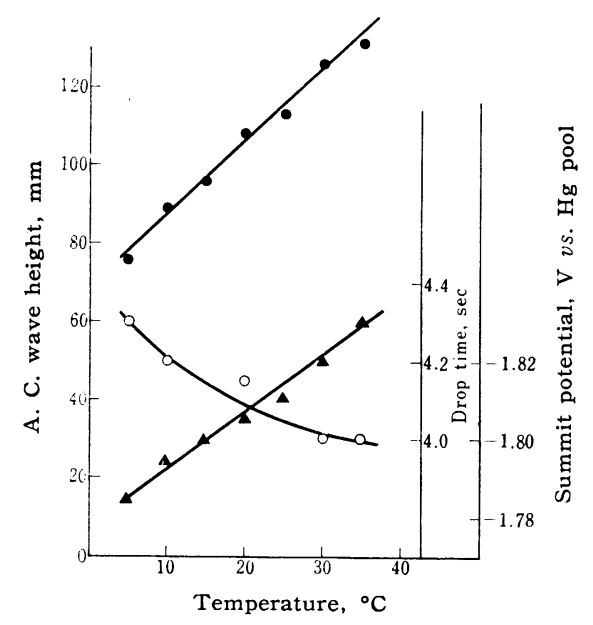

Fig. 5 Effects of temperature

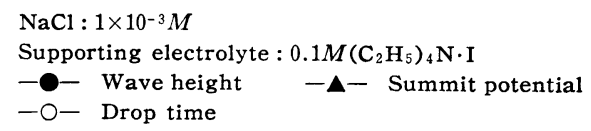

$3 \cdot 2 \cdot 5$ 水銀滴下時間 交流ポーラログラフでは水 銀柱の高さは波高にほとんど影響しないのが普通である が, 水銀柱の高さをかえて滴下時間を変化させ，これと 波高の関係を調べてみるとその結果は Fig. 6 に示すよ
うで，波高は滴下時間，したがって水銀柱の高さによっ て多少変化することがわかった. 変化の方向は直流法と 逆である。

\section{$3 \cdot 3$ 波高と濃度の関係}

$3 \cdot 2$ での検討の結果, 検量線の作成のための基礎的条 件が得られたので, 以後測定条件を $2 \cdot 1$ のように定め て, まず, 単独系における波高と濃度の関係について調 ベた. この場合, Fig. 1 のバリウムイオンについて例 示したように交流波の陽電位側基線に水平の 接線をひ き, この接線から頂点までを波高とした（単独の復極郕 イオンを含む溶液の場合にはピークより陰電位側の基線 も水平の接線にほぼ一致する).なお, TEA-I 中には 少量の被還元物質がしばしば存在し，ナトリウムおよび カリウムの交流波の位置に小さな波を与える.この場合 には支持電解質溶液について別にポーラログラムをとり 不純物の波高をさし引いた．塩化りチウムを支持電解質 とする場合もりチウム波がナトリウム, カリウム波著 しく重なるので，これも同様にりチウム波を別汇測定し てさし引いた。

$0.1 M$ TEA-I を支持電解質とした場合の結果を. Fig. 7 および Fig. 8 に示す.ナトリウム,カリウム,リチウ ムおよびバリウムイオンについては $10^{-3} \sim 10^{-5} M$ の濃 度範囲で原点を通る良好な直線関係が得られたが，カル シウムイオンの検量線は直線的でない.なおカリウム, ナトリウムおよびリチウムイオンの波高の比注それぞれ の拡散係数の平方根の比と大体において対応する.

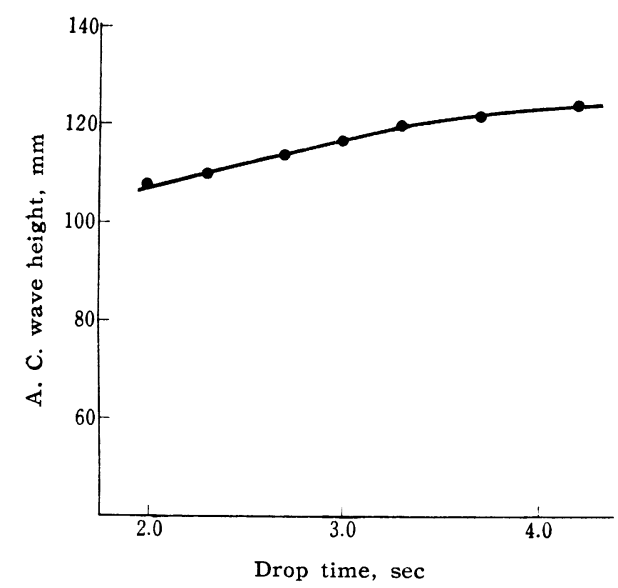

Fig. 6 Effect of drop time on sodium A. C. wave height $\mathrm{NaCl}: 1 \times 10^{-3} M$ Supporting electrolyte : $0.1 M\left(\mathrm{C}_{2} \mathrm{H}_{5}\right)_{4} \mathrm{~N} \cdot \mathrm{I}$

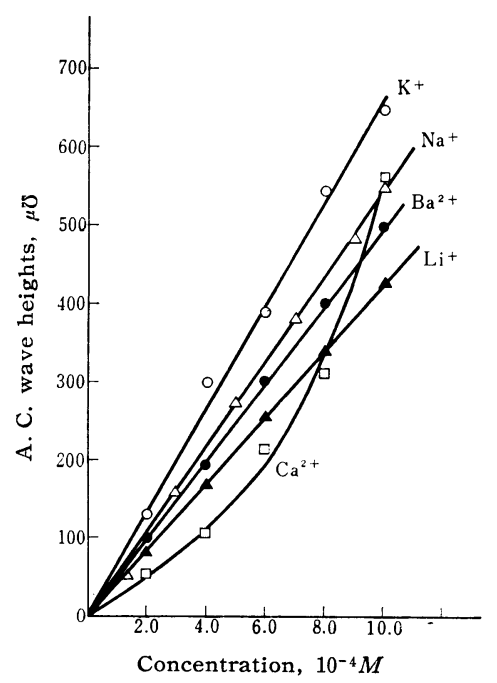

Fig. 7 Calibration lines (a)

Supporting electrolyte : $0.1 M\left(\mathrm{C}_{2} \mathrm{H}_{5}\right)_{4} \mathrm{~N} \cdot \mathrm{I}$ 


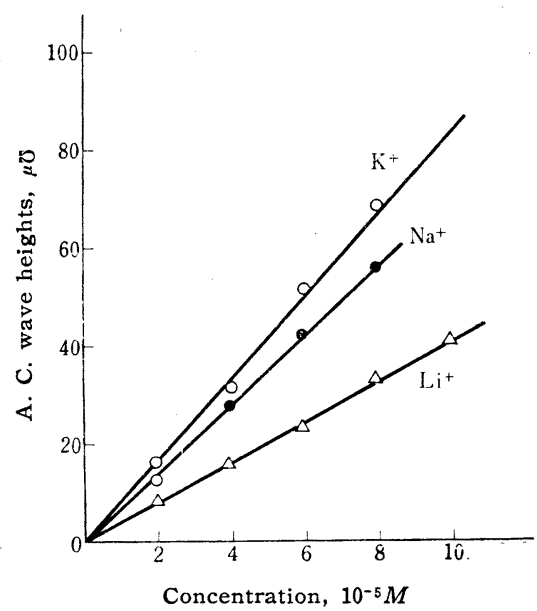

Fig. 8 Calibration lines (b) Supporting electrolyte : $0.1 M\left(\mathrm{C}_{2} \mathrm{H}_{5}\right)_{4} \mathrm{~N} \cdot \mathrm{I}$

次に $0.1 M$ の塩化リチウムを支持電解質として用い た場合の波高と濃度との関係は Fig. 9 に示すとおり で，バリウムイオンのみ原点を通る直線が得られた．䘏 化リチウムはバリウムイオンの定量の場合かなりすぐれ た支持電解質といえる。

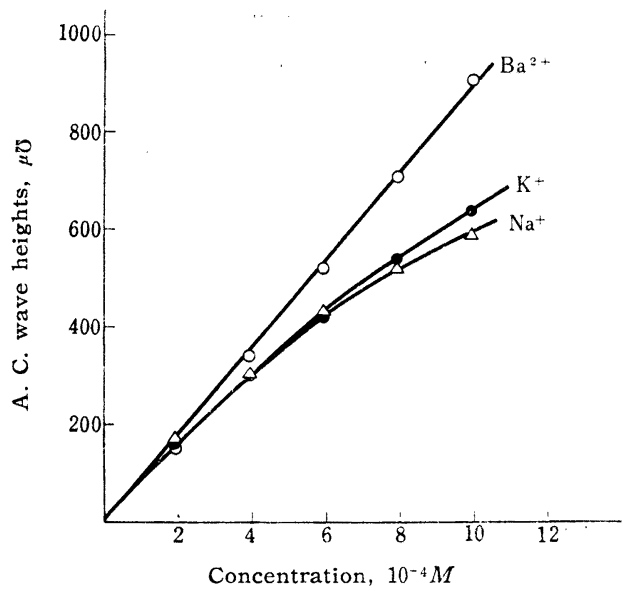

Fig. 9 Calibration lines (c) Supporting electrolyte: $0.1 M \mathrm{LiCl}$

\section{$3 \cdot 4$ ナトリウムとカリウムの分離定量}

ナトリウムとカリウムイオンは前述のように頂点電位 が接近していて交流ポーラログラフでもこのままでは分 離定量は不可能である. 従来, この分離手段としてすで に述ベたもの45)のほか, 最近ではカリウムイオンを T P Bで沈殿分離したのち，これをジメチルホルムアミ
ドに溶解してカリウムイオンの定量を行なう方法8) が報 告されている. 本報でも T P Bがカリウムイオンと難溶 性塩を形成することを利用して両アルカリイオン共存系 でのナトリウムイオンの定量ならびにカリウムイオンの 間接定量を試みた。

まず，沈殿の定量的生成を調べた，カリウムイオンを 含さ溶液に試薬 T P B 添加子ると次のように沈殿を生 ずる.

$$
\mathrm{K}^{+}+\mathrm{TPB}^{-} \rightleftarrows \mathrm{K}-\mathrm{TPB} \downarrow
$$

ここで K-TPB は TPB のカリウム塩示す. 溶液中 に溶存する K-TPB は完全に $\mathrm{K}^{+}$と TPB-に解離し ているとすると， $\mathrm{K}^{+}$および TPB-の濃度は次の溶解 度積 $k_{s}$ で規定される。

$$
k_{s}=\left[\mathrm{K}^{+}\right]\left[\mathrm{TPB}^{-}\right]=2.2 \times 10^{-8} 9
$$

初濃度 $C_{\mathrm{K}}$ のカリウムイオンの溶液に $C_{\mathrm{TPB}}$ モルの試 薬 TPB 萿加後， $x$ モルの沈殿が生じたとすると（2） 式は

$$
\left(C_{\mathrm{K}}-x\right)\left(C_{\mathrm{TPB}}-x\right)=k_{s}
$$

となるまた，カリウムイオンの単位濃度に対する波高 $\mu \mho / M$ を $k_{\mathrm{K}}$ で示すと，溶液中に存在するカリウムイ オンの波高 $i_{\mathrm{K}}$ は

$$
i_{\mathrm{K}}=k_{\mathrm{K}}\left(C_{\mathrm{K}}-x\right)
$$

となる・両式から

$$
\begin{aligned}
i_{\mathrm{K}}= & \frac{k_{\mathrm{K}}}{2} \cdot\left(C_{\mathrm{K}}-C_{\mathrm{TPB}}+\right. \\
& \left.\sqrt{\left(C_{\mathrm{K}}+C_{\mathrm{TPB}}\right)^{2}-4\left(C_{\mathrm{K}} \cdot C_{\mathrm{TPB}}-k_{s}\right)}\right)
\end{aligned}
$$

が得られる.また $1 \times 10^{-3} M$ のカリウムイオンを含む溶 液に Li-TPB を添加したときの波高の変化を実測し， これと同条件における (5) 式による計算值を比較する と Fig. 10 のと㧍りである. 抄， $k_{\mathrm{K}}$ の值注 Fig. 7 の結果を用いた. 両者はほぼ一致しているが, 若干の相 違は試薬 TPB の低濃度側では多少カリウムイオンが沈 殿に吸着されるためと思われる。

以上のようにカリウムイオンの沈殿はポーラログラム 上でもほぼ定量的であるので，ナトリウムとカリウムイ オンの共存系中のナトリウムイオンの分析堂試みた。ま ず，ナトリウムとカリウムイオン混合溶液に Li-TPB 溶液を加え，カリウムイオンを沈殿せしめ遠心分離す る. 次に上澄液の一定量に支持電解質として TEA-I を 加える.そのとき生ずる過剩の試薬 TBP と TEA-I 間 の難溶性塩をさらに遠心分離したのち，交流ボーラログ 
ラフにかけた．この場合 TPB と TEA-I 間の沈殿に よって $2 \%$ 程度の支持電解質の濃度低下があるがその影 響涊められない. $1 \times 10^{-3} M$ のカリウムイオンと共存 する〜10-4Mのナトリウムイオンの定量を行なった結果 をFig. 11 に示す. 原点を通る良好な直線で，またこれ 法さきのナトリウムイオン単独の場合のものとほとえど 一致している.これによってカリウムイオン中のナトリ ウムイオンの定量が可能である.

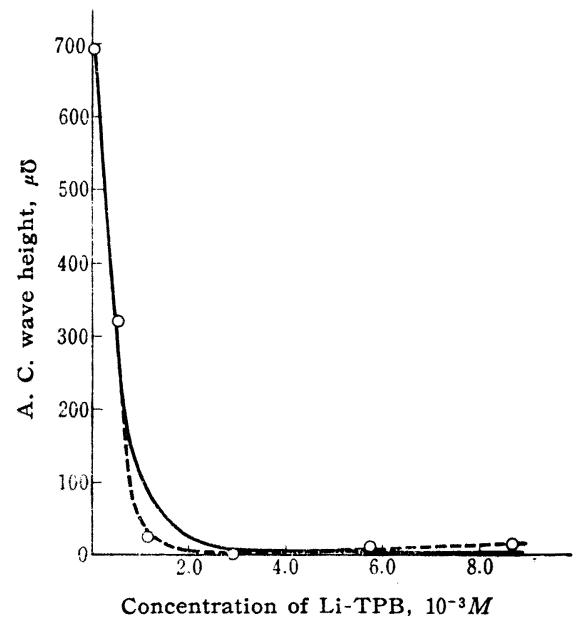

Fig. 10 Decrease of A. C. wave height of potassium ion by precipitation with Li-TPB Initial concentration of $\mathrm{KCl}: 1 \times 10^{-3} M$ Supporting electrolyte : $0.1 M\left(\mathrm{C}_{2} \mathrm{H}_{5}\right)_{4} \mathrm{~N} \cdot \mathrm{I}$ Solid line : Calculated values by eq. 5 Broken line: Observed values

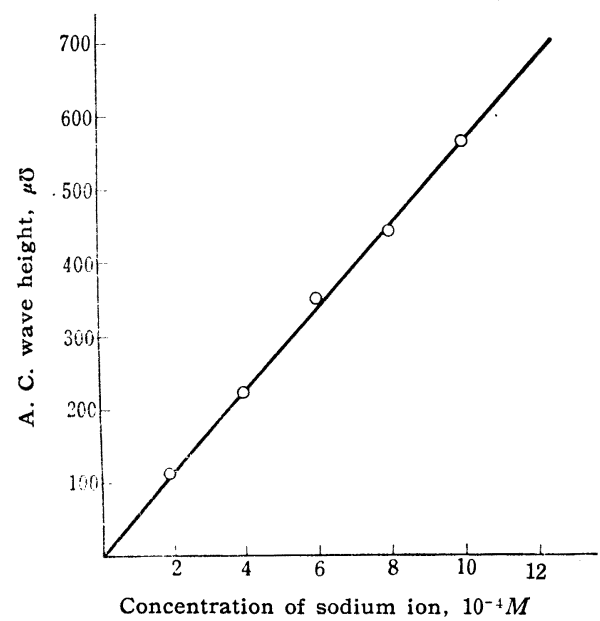

Fig. 11 Calibration line for separate determination of sodium ion in $1 \mathrm{mM} \mathrm{KCl}$ Supporting electrolyte : $0.1 M\left(\mathrm{C}_{2} \mathrm{H}_{5}\right)_{4} \mathrm{~N} \cdot \mathrm{I}$

\section{$3 \cdot 5$ ナトリゥムとカリウムの波高の加成性}

ナトリウムとカリウムイオンの共存系の波高の加成性 について検討した. 直流法においては $80 \%$ ジオキサン 系でナトリウムとカリウムイオンの波高は等しいといわ れている2). Fig. 12 は 0.1M TEA-I 安持電解質と した水溶液中でナトリウムとカリウムイオンの全濃度を $1 \times 10^{-3} M$ に保ち，その混合比を変えたときの波高の 変化を示した．これより波高について厳密ではないが近 似的に加成性が成立する。たがって，混合液について 交流波をとり，次に前述の Li-TPB によるカリウムの 沈殿分離を利用してナトリウムイオンのみの交流波を測 定すれば両波高の差はカリウムイオンの波高となり，そ の值からカリウムイオンの定量が可能である・ただし， 加成性に対する近似のためナトリウムとカリウムイオン が等量の場合カルシウムについて約 $3 \%$ 程度の誤差があ る.

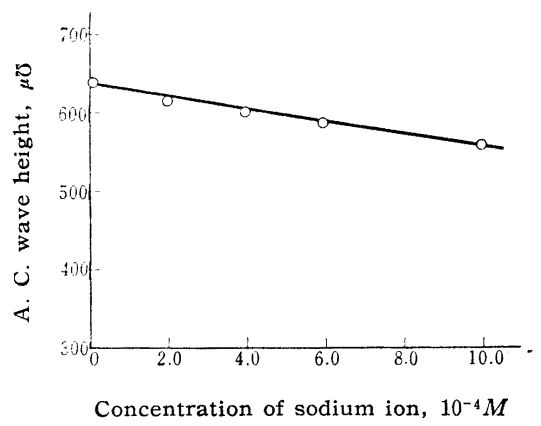

Fig. 12 Additivity of wave height in the mixed solutions of solium and potassium ions Total concentration of the depolarizer : $1 \mathrm{~m} M$ Supporting electrolyte : $0.1 M\left(\mathrm{C}_{2} \mathrm{H}_{5}\right)_{4} \mathrm{~N} \cdot \mathrm{I}$

\section{$3 \cdot 6$ アルカリ土類イオン中のアルカリの定量}

アルカリイオンの定量においてバリウムイオン以外の アルカリ土類イオンが共存するとこれらはアルカリイオ ンの交流波怎妨害するそこで，EDTAによる錯化を 利用してこの妨害を除く方法を考光検討した・アルカリ 土類イオンを含导試料溶液に Li-EDTA を加えるもの で，こ机によってカルシウムおよびマグネシウムイオン 中の〜 $10^{-5} M$ のナトリウムイオンおよびカリウムイオン を定量できることがわかった。その検量線を Fig. 13 に示した. この場合, 両イオンとも感度が多少低下し, また検量線がほぼ一致する点が Fig. 8 の場合と異なっ ている. TEA-OH を支持電解質とし，これに EDTA を添加併用してもマグネシウムおよびカルシウム波の影 
響は消失する・これによってこれらアルカリ土類中のリ チウムイオンの定量も可能と推測される.

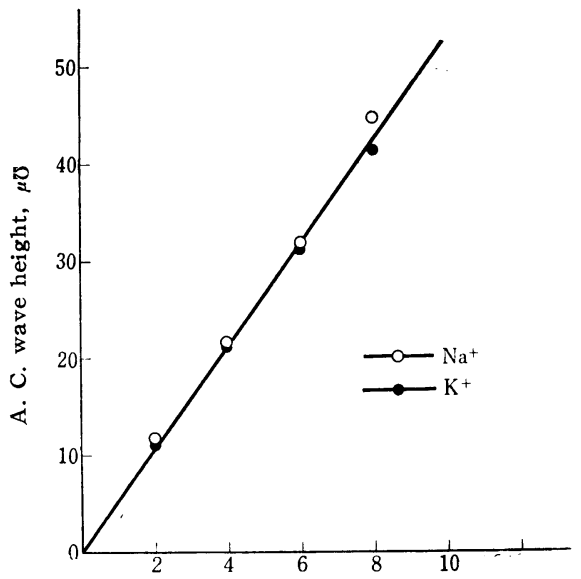

Concentration of sodium ion or potassium ion, $10^{-5} \mathrm{M}$

Fig. 13 Calibration lines of sodium and potassium ions in the mixed solution of $1 \mathrm{mM}$ calcium and magnesium ions

Supporting electrolyte : $0.1 M\left(\mathrm{C}_{2} \mathrm{H}_{5}\right)_{4} \mathrm{~N} \cdot \mathrm{I}$ Masking agent : $4 \times 10^{-3} M$ Li-EDTA

本研究に際し，種々ご教示を賜わった九州大学工学部 清山哲郎教授ならびに上野景平教授に深く感謝いたしま के.

(電気化学協会第 31 回大会学術講演会に扣いて講演)

\section{交献}

1）館勇：“ポーラログラフィー”, (1954), (岩波).

2) 品川睦明：“ポーラログラフ分析法”, p. 184 (1957), (共立出版).

3) I. M. Kolthoff, J. J. Lingane : "Polarography”, Vol. 2, (1952), (Interscience Pub.).

4) D. Lohuis, V. W. Meloche, C. Juday: Trans. Wisconsin Acad. Sci., 31, 285 (1938).
5) K. Abresch : Angew. Chem., 48, 683 (1935).

6) J. E. B. Randles, K. W. Somerton: Trans. Faraday Soc., 48, 951 (1952).

7) K. Schwabe, H. Jehring: Z. Anal. Chem., 173, 36 (1960).

8) A. F. Findeis : Anal. Chem., 28, 209 (1956).

9) R. T. Pflaum, L. C. Howick : ibid., 28, 1542 (1956).

$$
\text { 约 }
$$

A. C. polarographic determination of alkali and alkaline earth metal ions. Nobuhiko IsHIBASHI, Hitoshi KoHara and Toshihide Haraguchi (Faculty of Engineering, University of Kyushu, Fukuoka)

A. C. polarographic behaviors of several alkali and alkaline earth metal ions (lithium, sodium, potassium, magnesium, calcium and barium) are investigated in their concentration ranges of $10^{-3}$ $\sim_{10^{-5} M}$. Well-difined A. C. waves are obtained for the ions examined except for magnesium, by use of $0.1 M$ tetraethylammonium iodide (TEA-I) as a supporting electrolyte.

The effects of TEA-I concentration, $\mathrm{pH}$, dissolved oxygen, drop time of mercury and temperature are examined on the A. C. wave of sodium ion, and linear calibration lines are obtained for the pure alkali ions and barium ion. Litium chloride is another good supporting electrolyte for the determination of barium ion.

The calibration line for calcium ion has a slight curvature. Magnesium ion does not show any reproducible A. C. wave and disturbs the analysis of the alkali metal ions. As for the mixed solution of sodium and potassium ions, the additivity of A. C. wave heights of both ions together with the precipitation of potassium by lithium tetraphenylborate permits the determination of $10^{-4} M$ sodium ion in the presence of several folds potassium ion. An indirect determination of potassium ion is also possible.

The determination of trace of sodium and potassium ions in the alkaline earth metal ions is shown to be successful by masking the latter ions with Li-EDTA. A similar method of lithium analysis is suggested.

(Received Sep. 1, 1964) 